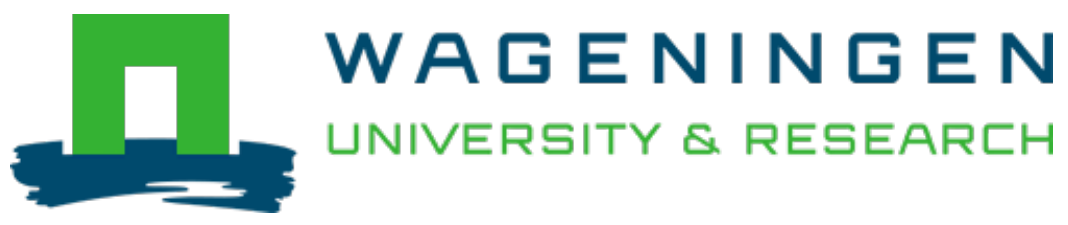

\title{
Effect of water activity on production and activity of Rhizopus oligosporus polysaccharides
}

\author{
Applied Microbiology and Biotechnology \\ Sarrette, M.; Nout, M.J.R.; Gervais, P.; Rombouts, F.M. \\ https://doi.org/10.1007/BF00180961
}

This publication is made publicly available in the institutional repository of Wageningen University and Research, under the terms of article $25 \mathrm{fa}$ of the Dutch Copyright Act, also known as the Amendment Taverne. This has been done with explicit consent by the author.

Article 25 fa states that the author of a short scientific work funded either wholly or partially by Dutch public funds is entitled to make that work publicly available for no consideration following a reasonable period of time after the work was first published, provided that clear reference is made to the source of the first publication of the work.

This publication is distributed under The Association of Universities in the Netherlands (VSNU) 'Article $25 \mathrm{fa}$ implementation' project. In this project research outputs of researchers employed by Dutch Universities that comply with the legal requirements of Article $25 \mathrm{fa}$ of the Dutch Copyright Act are distributed online and free of cost or other barriers in institutional repositories. Research outputs are distributed six months after their first online publication in the original published version and with proper attribution to the source of the original publication.

You are permitted to download and use the publication for personal purposes. All rights remain with the author(s) and / or copyright owner(s) of this work. Any use of the publication or parts of it other than authorised under article $25 \mathrm{fa}$ of the Dutch Copyright act is prohibited. Wageningen University \& Research and the author(s) of this publication shall not be held responsible or liable for any damages resulting from your (re)use of this publication.

For questions regarding the public availability of this publication please contact openscience.library@wur.nl 


\title{
Effect of water activity on production and activity of Rhizopus oligosporus polysaccharidases
}

\author{
M. Sarrette ${ }^{1}$, M. J. R. Nout ${ }^{2}$, P. Gervais ${ }^{1}$, and F. M. Rombouts ${ }^{2}$ \\ ${ }^{1}$ Laboratoire de Génie des Procédés, Ens. Bana Cum, F-21000 Dijon, France \\ ${ }^{2}$ Department of Food Science, Agricultural University, Bomenweg 2, NL-6703 HD Wageningen, The Netherlands
}

Received 18 November 1991/Accepted 13 February 1992

Summary. During tempeh fermentation, Rhizopus oligosporus produced polysaccharidases to degrade soya bean cell walls; the maximum activity for all polysaccharidases tested occurred $20-30 \mathrm{~h}$ after inoculation. $R$. oligosporus was also grown in a soya bean extract model medium to which glycerol was added to control water activity $\left(a_{\mathrm{w}}\right)$. The overall activities of the major enzymes produced by the fungus, polygalacturonase, endocellulase and xylanase, appeared to be strongly influenced by $a_{\mathrm{w}}$. The production of enzymes as well as their specific activities were affected by $a_{\mathrm{w}}$. The optimum $a_{\mathrm{w}}$ for polygalacturonase and xylanase activity coincided with that for mycelial growth, namely $0.99-1.00$. In contrast, the optimum $a_{\mathrm{w}}$ for (endo)cellulase was 0.98 , at which mycelial growth was significantly reduced.

\section{Introduction}

Water is a fundamental prerequisite for biological activity. Since microorganisms do not recognize the water content of a particular material, but rather the amount of available water, food microbiologists prefer to use the parameter "water activity" instead of the water content.

The influence of water activity $\left(a_{\mathrm{w}}\right)$ on microbial growth (Beuchat 1983) and production of metabolites (Mattiasson and Hahn-Hagerdal 1982) is widely recognized. The effect of $a_{\mathrm{w}}$ on production of, for example, aroma compounds has been studied (Gervais and Sarrette 1990); the latter can be considered as resulting from particular metabolic pathways in which enzymes are involved. Considering the protein nature of enzymes, the influence of $a_{\mathrm{w}}$ on protein stability (LarettaGarde et al. 1987) and activity (Hahn-Hägerdal et al. 1987) as well as the role of water as a vehicle for substrate transport and as a reactant, it may be expected that $a_{\mathrm{w}}$ affects enzymatic transformation during fermentations. Consequently, in fermented foods, enzyme pro-

Correspondence to: $\mathrm{M}$. Sarrette duction (Kaji and Yoshihara 1969) as well as enzyme activity (Chou and Ho 1988) are of importance in view of the optimization of metabolite production.

Tempeh is obtained by solid substrate fermentation of soya beans with Rhizopus oligosporus, a filamentous fungus (Nout and Rombouts 1990). The mycelium is able to penetrate the cell wall of the beans (Jurus and Sundberg 1976) in order to digest the cell constituents and improve the nutritive value of beans (Shurtleff and Aoyagi 1979). The activity of polysaccharide-degrading enzymes (Okolie 1988) possibly contributes to this penetration.

The present report deals with the influence of $a_{\mathrm{w}}$ on the production and activity of polysaccharidases, notably polygalacturonase, cellulase and xylanase by $R$. oligosporus during tempeh fermentation and in model systems.

\section{Materials and methods}

Microorganism. R. oligosporus NRRL 5905 was grown on malt extract bouillon (MEB, Oxoid CM57) at $30^{\circ} \mathrm{C}$ for 7 days and maintained on malt extract agar (MEA, Oxoid CM59) at $4^{\circ} \mathrm{C}$ for a maximum of 4 months.

Preparation of spore suspension for tempeh fermentation. $R$. oligosporus was grown for 2 days on slants of MEA at $30^{\circ} \mathrm{C}$. A spore suspension was obtained by shaking slant cultures on a vortex mixer with $10 \mathrm{ml}$ of aqueous $0.05 \%$ Tween 80 .

Medium and inoculation. Medium 1: in order to determine which polysaccharidases are produced by $R$. oligosporus, it was grown as in the traditional tempeh fermentation process (Nout and Rombouts 1990). Dehulled soya beans were soaked in water overnight at room temperature $\left(25^{\circ} \mathrm{C}\right)$, then boiled for $50 \mathrm{~min}$. After discarding the cooking water, the hot beans were spread in a thin layer and cooled to room temperature; subsequently, they were inoculated with a spore suspension of $R$. oligosporus $\left(10^{6} \mathrm{cfu} / \mathrm{kg}\right.$ of cooked soya beans). The inoculated soya beans were packed firmly in perforated plastic boxes, and incubated at $30^{\circ} \mathrm{C}$ for $50 \mathrm{~h}$, yielding fresh tempeh.

Medium 2: in order to study the effect of $a_{\mathrm{w}}$ on the production of enzymes and their activities, $R$. oligosporus was grown on a model substrate prepared with soya beans. This method eliminates 
problems of heat and mass transfer and measurement of $a_{\mathrm{w}}$ that occur in tempeh. This substrate named soya extract agar (SEA) was obtained by soaking dehulled soya beans overnight (Nout 1989), followed by cooking them in the soak water for $10 \mathrm{~min}$, and by precipitation of soluble proteins at consecutive low(4.5) and high(9.0) $\mathrm{pH}$. The medium contained a minimum of $1 \%$ of oligosaccharides, and had a final $\mathrm{pH}$ of 4,$5 ; 2 \%$ agar (Oxoid L13) was added. After sterilisation for $15 \mathrm{~min}$ at $120^{\circ} \mathrm{C}$, the medium was poured into petri dishes with perforated covers. SEA plates were inoculated at the centre with a piece of mycelium of $8 \mathrm{~mm}$ diameter (Gervais and Sarrette 1990) taken from a previous culture $\left(3\right.$ days at $30^{\circ} \mathrm{C}$ ).

Control of $a_{w}$ in the SEA medium. Before sterilisation, an amount of glycerol calculated using the Norrish equation (Norrish 1966) was added to SEA medium in order to produce $a_{\mathrm{w}}$ values ranging from 0.96 to values close to 1.00 . After inoculation, petri dishes were incubated at $30^{\circ} \mathrm{C}$ in chambers with a relative humidity equivalent to the $a_{\mathrm{w}}$ of the respective SEA plates, maintained by glycerol-water mixtures to which sodium azide had been added at $0.01 \%$ as a preservative.

Control of $a_{w}$ in enzyme assay. The influence of $a_{\mathrm{w}}$ on enzyme activities was measured by adding adequate quantities of glycerol to the enzyme-substrate solutions.

Growth measurement in SEA medium. Fungal growth on SEA was measured by either (a) radial growth or by (b) biomass determination. For (a), colony diameters were measured along two perpendicular axes marked on the upper part of the petri dishes. For (b), the culture and its medium were removed from the petri dish, brought to boil in a microwave oven, and subsequently vacuum filtered (Schleicher and Schuell 520B). Three successive washings of the filter were made, each with $50 \mathrm{ml}$ distilled water at $95^{\circ} \mathrm{C}$. The filter was dried overnight at $110^{\circ} \mathrm{C}$, then placed in a desiccator and weighed.

Enzyme recovery. For tempeh fermentation, a perforated cylindrical mould of $70 \mathrm{~mm}$ diameter, closed with perforated covers at both ends was used. The cylinder and covers contained holes with a diameter of $2 \mathrm{~mm}$, spaced $2 \mathrm{~cm}$ apart. For sampling, a slice of $30 \mathrm{~mm}$ thickness of fermented soya beans was cut from one side of the cylinder and the resulting air space was filled by pushing the cover inwards onto the remaining fermenting beans; the next sample was taken from the other side of the cylinder, so that each sample had undergone similar conditions of aeration.

For the cultures grown on SEA in petri dishes, two samples were taken after 28 and $46 \mathrm{~h}$ of incubation.

Samples ( $70 \mathrm{~g}$ each in the case of tempeh fermentation and 60 each in the case of petri dishes) were mixed in a blender (MSE, Beun de Ronde, The Netherlands) at high speed with $200 \mathrm{ml}$ of $50 \mathrm{~mm}$ sodium acetate buffer, $\mathrm{pH} 5.0$, then centrifuged at $4^{\circ} \mathrm{C}$ for $20 \mathrm{~min}$ at $10000 \mathrm{rpm}$. The supernatant was kept and dialysed against 51 water in an acetate dialysis tube at $4^{\circ} \mathrm{C}$ for $36 \mathrm{~h}$; the water was changed every $10 \mathrm{~h}$. The dialysis enabled removal of glycerol from SEA media and the obtention of enzyme extracts at a water activity close to 1.00 . The dialysed solutions were frozen and subsequently freeze-dried. The dried extract was dissolved in $50 \mathrm{~mm}$ sodium acetate buffer, $\mathrm{pH} 5.0$.

Enzyme assays. Activities of enzymes were assayed by determination of reducing sugars released by the hydrolysis of polygalacturonic acid (ICN pharmaceuticals, Cleveland, Ohio, USA) for polygalacturonase activity; Avicell (type SF Serva, Heidelberg, FRG) for exocellulase activity; AF0305 (type Akucell, Akzo, The Netherlands) for endocellulase activity; highly branched xylan (from oat spelts, Sigma, St. Louis, Mo., USA) for xylanase activity; and UFR arabinan obtained by ultrafiltration of clarified apple juice produced from apple pulp using technical pectinase and cellulase enzymes (Voragen et al. 1986) for arabinase activity, respectively.
A mixture of $0.5 \mathrm{ml}$, containing $100 \mu \mathrm{l}(0.5 \% \mathrm{w} / \mathrm{v})$ substrate, $50 \mu \mathrm{l}$ enzyme solution and $350 \mu 150 \mathrm{mM}$ sodium acetate buffer, $\mathrm{pH} 5.0$, was incubated for $1 \mathrm{~h}$ at $30^{\circ} \mathrm{C}$. The release of reducing sugars was determined with the Nelson Somogyi method (Spiro 1966) using a Beckman DU-64 spectrophotometer at $520 \mathrm{~nm}$.

Activities of $\beta$-D-glucosidase, $\alpha$-D-galactosidase, $\beta$-D-xylosidase, $\alpha$-L-arabinofuranosidase and $\alpha$-D-glucosidase were measured using their corresponding p-nitrophenol (PNP) derivatives as substrates. An amount of $0.4 \mathrm{ml}$ enzyme solution was added to $0.1 \mathrm{ml}$ PNP-substrate solution $(0.1 \%$ in $50 \mathrm{~mm}$ acetate buffer, $\mathrm{pH}$ 5.0 ) and incubated for $1 \mathrm{~h}$ at $30^{\circ} \mathrm{C}$. The reaction was stopped by addition of $0.5 \mathrm{M}$ glycine buffer, $\mathrm{pH} 9.0$ and $0.002 \mathrm{M}$ EDTA. The released PNP was measured at $400 \mathrm{~nm}$, and quantified using a molar absorption coefficient of 13700 .

All activities are expressed in international units (U). Measurements of enzyme activities were repeated three times: differences between repetitions differed by less than $7 \%$. All experiments were carried out in duplicate: the variation coefficient between duplicates was less than $20 \%$.

\section{Results}

\section{Enzymes produced in tempeh}

Since soybean cell walls contain $30 \%$ pectic substances, $50 \%$ hemicelluloses and $20 \%$ celluloses on a dry weight basis (Kikuchi et al. 1971), we investigated polygalacturonase, cellulase, xylanase and arabinase activities during tempeh fermentation. No pectate lyase and no exocellulase activities were measured. From Fig. 1 it can be seen that polygalacturonase activity was detected after $10 \mathrm{~h}$ of fermentation. A few hours later, endocellulase, xylanase and arabinase activities could be detected. The maximum activity for all enzymes was found between 20 and $30 \mathrm{~h}$ of fermentation.

Figure 2 shows activities of glycosidases produced in tempeh. Stachyose is one of the antinutritional compounds found in soya beans. During tempeh fermentation, the production of $\alpha$-D-galactosidase contributes to its degradation. The $\alpha$-galactosidase activity we measured after $24 \mathrm{~h}$ of tempeh fermentation corresponds with that found by Van de Riet et al. (1987).

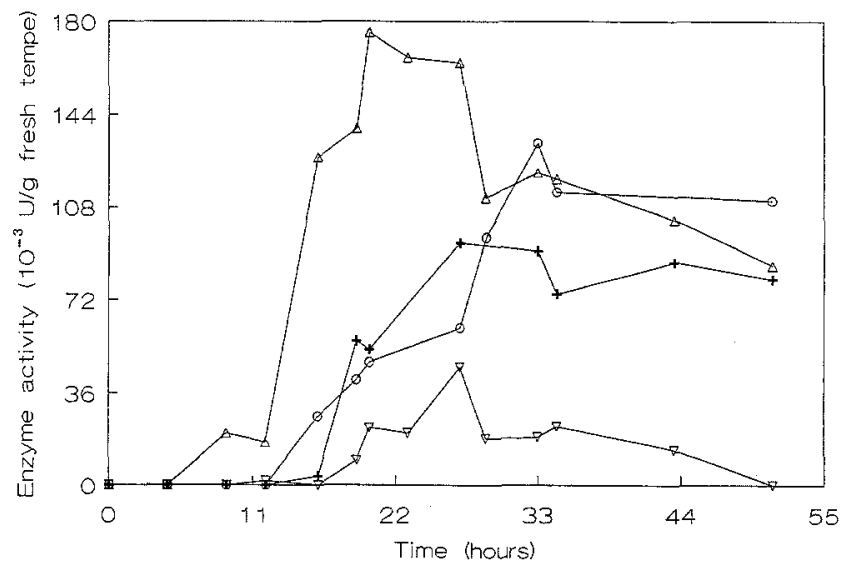

Fig. 1. Time course of polygalacturonase $(\Delta)$, endocellulase $(O)$, xylanase $(+)$ and arabinase $(\nabla)$ activity of Rhizopus oligosporus during tempeh fermentation: $U$, International units 


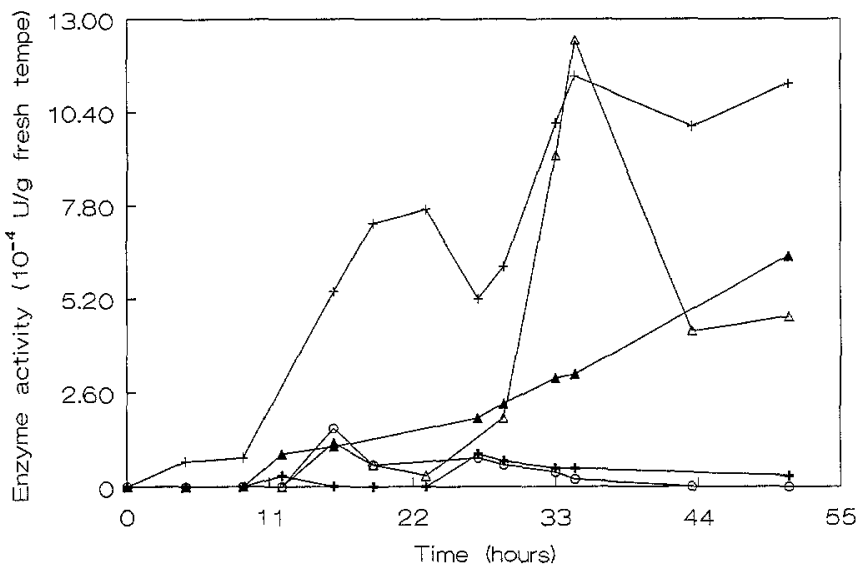

Fig. 2. Time course of $\beta$-D-glucosidase $(+), \alpha$-D-galactosidase $(\Delta)$, $\beta$-D-xylosidase $(O), \alpha$-L-arabinosidase $(+)$ and $\alpha$-D-glucosidase (A) of $R$. oligosporus during tempeh fermentation: U, International units

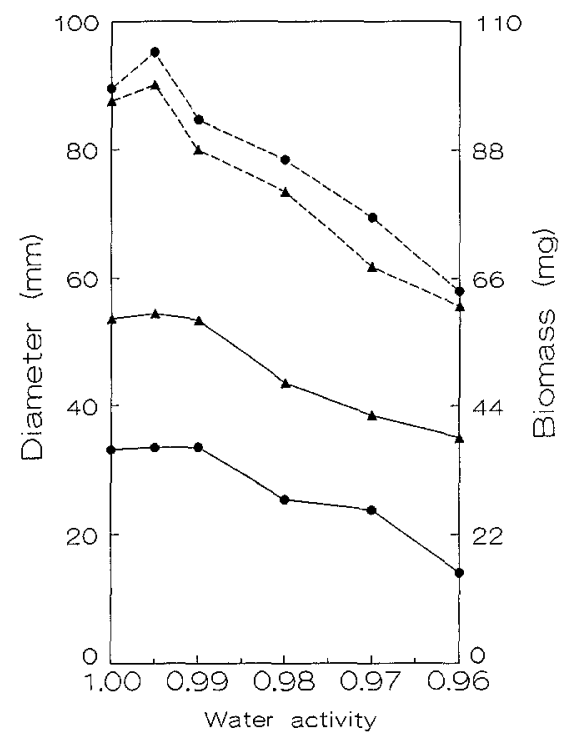

Fig. 3. Effect of water activity on the growth of $R$. oligosporus on soya extract agar medium: $\boldsymbol{\Delta}$, diameter of the colony; $\boldsymbol{\theta}$, biomass (dry weight); - , after $28 \mathrm{~h}$ of fermentation; ----, after $46 \mathrm{~h}$ of fermentation

Influence of $a_{w}$ on mycelial growth and enzymes produced on SEA medium

Mycelial growth. Figure 3 shows that the diameter and dry weight of $R$. oligosporus colonies decreased with lower $a_{\mathrm{w}}$ values.

Influence of $a_{w}$ on hydrolytic reactions of enzymes. As previously mentioned, the effect of $a_{\mathrm{w}}$ on the production of enzymes should be distinguished from the effect on their activity. Since polygalacturonase, endocellulase and xylanase were the predominant polysaccharidases produced by $R$. oligosporus in tempeh, we investigated the effect of $a_{\mathrm{w}}$ on their hydrolytic capacity by the $a_{\mathrm{w}}$ control of reaction mixtures through glycerol addition. Two kinds of enzymes were used in this experiment: en-

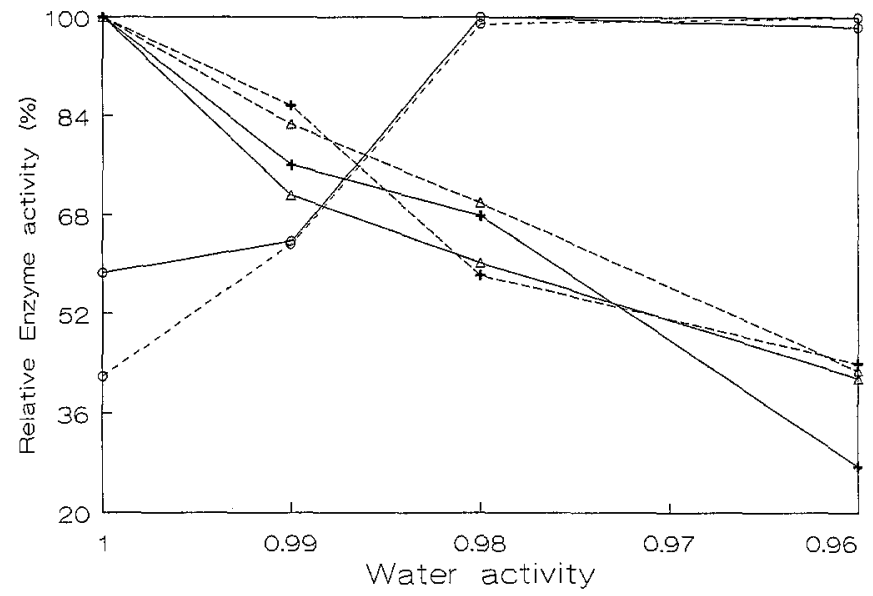

Fig. 4. Effect of water activity $\left(a_{\mathrm{w}}\right)$ on the percentage of the product released in hydrolytic reactions of polygalacturonase $(\Delta)$, endocellulase $(O)$ and xylanase $(+)$ : $-\ldots$, enzyme produced in medium at $a_{\mathrm{w}}=1.00 ;---$, enzyme produced in medium at $a_{\mathrm{w}}=0.98$

zymes produced by the fungus grown on a medium at $a_{\mathrm{w}}$ close to 1.00 and corresponding enzymes formed by the fungus grown at $a_{\mathrm{w}} 0.98$. Figure 4 shows that the activity of polygalacturonase, xylanase and cellulase were influenced by the $a_{\mathrm{w}}$ of the reaction mixture in which they were incubated. Maximum polygalacturonase activity was observed at an $a_{\mathrm{w}}$ close to 1.00 , whereas it decreased significantly at lower $a_{\mathrm{w}}$, to $42 \%$ at $a_{\mathrm{w}}=0.96$. A similar effect of $a_{\mathrm{w}}$ was detected with the xylanases. There was a decrease in relative enzyme activity at reduced $a_{\mathrm{w}}$, of the same order of magnitude as observed with the polygalacturonases. The behaviour of cellulases was very different. Whereas the maximum relative enzyme activity was observed at a $a_{\mathrm{w}}$ between 0.98 and 0.96 , it decreased with higher $a_{\mathrm{w}}$ to only approximately $50 \%$ at $a_{\mathrm{w}}$ close to 1.00 .

There were no significant differences between the behaviour of enzymes produced at $a_{\mathrm{w}}=0.98$ and enzymes produced at $a_{\mathrm{w}}$ close to 1.00 , except for cellulase activity measured at $a_{\mathrm{w}}$ close to 1.00 and xylanase activity measured at $a_{\mathrm{w}}=0.96$. The measurement of kinetic parameters of polygalacturonase activity incubated at $a_{\mathrm{w}}$ close to 1.00 and $a_{\mathrm{w}}=0.96$ revealed that the maximum reaction velocity $\left(V_{\max }\right)$ was affected by $a_{\mathrm{w}}$. For instance, at $a_{\mathrm{w}}=0.96, V_{\max }=3.05 \mathrm{nmol}$ of reducing sugars $/ \mathrm{min}$, but at $a_{\mathrm{w}}=1.00, V_{\max }$ was $4.25 \mathrm{nmol}$ of reducing sugars/ min. However, the $K_{\mathrm{m}}$ values $(0.41 \mathrm{mg} / \mathrm{ml})$ were the same under both reaction conditions.

Influence of $a_{w}$ on enzyme production. The objective of this experiment was to assess the influence of $a_{\mathrm{w}}$ on the production of some extracellular enzymes by $R$. oligosporus. The fungus was grown in SEA medium at different $a_{\mathrm{w}}$ ranging from 1.00 to 0.96 . Subsequently, enzymes were extracted and their activity was measured at $a_{\mathrm{w}}$ close to 1.00 without addition of any $a_{\mathrm{w}}$ depressor. All results concerning cellulase activity were corrected for the influence of $a_{\mathrm{w}}$ on enzyme assays presented above. Figure 5 presents the production of the enzymes 


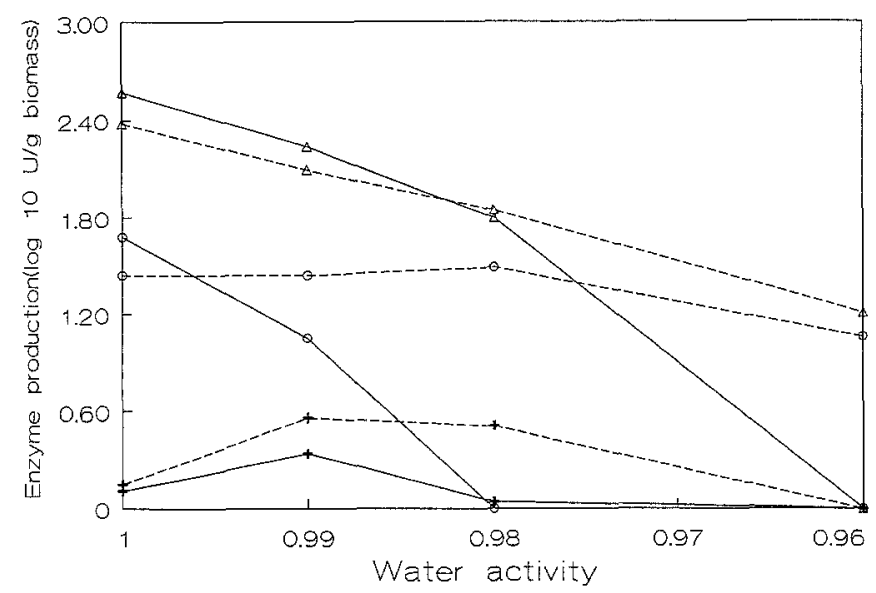

Fig. 5. Effect of water activity on enzyme production per unit of mycelial dry weight: $\Delta$, polygalacturonase; $O$, endocellulase; + , xylanase; - after $28 \mathrm{~h}$ of fermentation; ----, after $46 \mathrm{~h}$ of fermentation: $U$, International units

expressed per unit of biomass dry weight. After $28 \mathrm{~h}$ of fermentation at $a_{\mathrm{w}}=0.96$, the mycelial growth was very poor and it was not possible to measure any enzyme activity. In the culture medium used, an $a_{\mathrm{w}}$ close to 1.00 favoured the production of polygalacturonase. In the $a_{\mathrm{w}}$ range $1.00-0.98$, there were no great differences in enzyme activity after $28 \mathrm{~h}$ or $46 \mathrm{~h}$. With xylanase, we observed an increased enzyme production at $46 \mathrm{~h}$ compared to $28 \mathrm{~h}$ for all $a_{\mathrm{w}}$ values, and this increase was even more pronounced at low $a_{\mathrm{w}}$. At $28 \mathrm{~h}$, the optimum $a_{\mathrm{w}}$ for xylanase production was close to 0.99 , and at $46 \mathrm{~h}$ there was no significant difference between $a_{\mathrm{w}}=0.99$ and $a_{\mathrm{w}}=0.98$. After $46 \mathrm{~h}$, there was more enzyme produced at $a_{\mathrm{w}}$ close to 1.00 than at $a_{\mathrm{w}}=0.96$. With cellulase, results after $28 \mathrm{~h}$ did not show the same pattern as those after $46 \mathrm{~h}$. Whereas the endocellulase production was strongly reduced at $a_{\mathrm{w}}=0.98$ after $28 \mathrm{~h}$ of fermentation, the $a_{\mathrm{w}}$ had no significant effect after $46 \mathrm{~h}$.

\section{Discussion}

Polygalacturonase was first detected in tempeh, followed by endocellulase, xylanase and arabinase. Similar patterns were observed by Cooper and Wood (1975) who found that with Verticillium albo-atrum, production of polysaccharidases occurred in a sequential manner and that the first enzyme to be detected was polygalacturonase. This sequential appearance probably reflects the physicochemical accessibility of bean cell wall polymers, resulting in induction as successive substrates become available during progressive degradation of the cell wall. Polygalacturonase is also a major enzyme in $R$. stolonifer (Manachini et al. 1987) and in $R$. arrhizus (Sachde et al. 1987). Whitaker (1978) mentioned earlier that $R$. oligosporus produces pectinase activity.

Although the enzyme activities that we detected are not very high compared with those of fungi used commercially for the production of polysaccharidases, and
$R$. oligosporus is known mainly for its protease and lipase production, our findings show undoubtedly that the $R$. oligosporus enzymes can degrade soya bean cellwall components.

The fact that certain enzymes such as $\beta$-D-glucosidase do not show a gradual increase during the fermentation but rather have two maximum values, could be due to the production of two or more isoenzymes that degrade the same substrate but are not synthesized at the same time. Their synthesis might depend on the nature of the compounds to be hydrolysed in the medium.

It appears that the moment at which the highest enzyme activities were found $(20-30 \mathrm{~h})$, did not correspond with that chosen to stop tempeh fermentation, usually 2 days. We hypothesize that the enzymatic disruption of bean cell walls occurs during the early stages, and that the conversion of proteins and lipids takes place subsequently. This hypothesis is supported by the data of Chou and Ho (1988), who found that the highest yield of $\alpha$-galactosidase during sufu preparation by Actinomucor taïwanensis was observed after $24 \mathrm{~h}$ of fermentation, whereas the highest yield of lipase and protease occurred after $48 \mathrm{~h}$. Another explanation is offered by Sudarmadji (1977) who prepared tempeh with a pure culture of $R$. oligosporus incubated at $32^{\circ} \mathrm{C}$, and observed the appearance of the mycelium on beans at the same time as in our experiment, i.e. after $20 \mathrm{~h}$ of incubation. He measured the temperature at the centre of the cakes (for $41 \mathrm{~h}$ ) and concluded that the fermentation process may be differentiated into three phases. During the first phase $(0-30 \mathrm{~h})$, there was a rapid increase in total free fatty acids (maximum lipase activity), mould growth (estimated visually) and temperature at the centre of the cake. The end of this phase corresponded to the moment at which we found maximum activities of polysaccharidases. At the start of the second phase, tempeh was ready to be harvested (30-50 h), attaining its typical flavour, colour and texture during this period. The third phase $(>50 \mathrm{~h})$ corresponded to the spoilage of tempeh by bacteria and to the development of an unpleasant taste. According to Sudarmadji (1977), mould growth slows down at the end of the first phase; this stage corresponds to the onset of decreasing enzyme activities found by us. Thus, it appears that there is a good relationship between polysaccharidase activities and growth of mycelium. This consideration is of importance since there is no possibility of measuring mycelial biomass directly during tempeh fermentation.

Concerning the influence of $a_{\mathrm{w}}$ on the growth of the fungus on SEA medium, Wang et al. (1974) reported already that the protease production and mycelial growth of $R$. oligosporus grown on a solid substrate, were more influenced by the moisture content of the medium than by incubation time. Wang et al. (1974) also indicated that many members of the order Mucorales, to which $R$. oligosporus belongs, require a relative humidity near $100 \%$ to grow best. We found an optimum $a_{\mathrm{w}}$ for growth of 0.995 . This corresponds with the findings of Gervais et al. (1988) for Trichoderma viride.

Concerning the effect of $a_{\mathrm{w}}$ on the hydrolytic reactions of enzymes, it appears that $a_{\mathrm{w}}$ affects the $V_{\max }$ of 
the hydrolysis but not the affinity of the enzyme for the substrate. As only the velocity was affected, the influence of $a_{\mathrm{w}}$ probably resulted from a first-order noncompetitive inhibition. Hydrolytic enzymes split off a part of the substrate molecule while forming an acyl-enzyme intermediate. In this experiment, reduced $a_{\mathrm{w}}$ did not affect the rate of enzyme-substrate complex and acyl-enzyme formation. The $K_{\mathrm{m}}$ value found in our experiments is comparable with the values found by $\mathrm{Ma}$ nachini et al. (1987) and Liu and Luh (1978) who worked with an endo-polygalacturonase produced by $R$. stolonifer and $R$. arrhizus, respectively.

The fact that the production of polygalacturonase is not very different after $28 \mathrm{~h}$ or $46 \mathrm{~h}$ means that already after $28 \mathrm{~h}$, the fungus had produced the major part of the polygalacturonase enzyme; this corresponds with Fig. 1 where polygalacturonase was the first enzyme to be synthesized in tempeh. Only at $a_{\mathrm{w}}=0.96$ was the polygalacturonase production significantly more important after $46 \mathrm{~h}$ than after $28 \mathrm{~h}$. However, this was due to the long lag phase for mycelial growth at this $a_{\mathrm{w}}$. The different behaviour of cellulase production between $28 \mathrm{~h}$ and $46 \mathrm{~h}$ of fermentation could be related to the fact that cellulase synthesis by fungi occurs very often after polygalacturonase and xylanase synthesis. In tempeh the maximum production of cellulase also occurred after that of polygalacturonase, but its maximum activity was close to that of xylanase. On the whole, it appears that $28 \mathrm{~h}$ of fermentation is too short a period to allow comparisons, and that samples extracted after $46 \mathrm{~h}$ are more representative of enzyme production capability.

With regard to the production of enzymes per unit of biomass dry weight, $a_{\mathrm{w}}=0.98$ stimulated cellulase production by the mycelium, $a_{\mathrm{w}}=0.99$ was optimum for xylanase, and $a_{\mathrm{w}}=1.00$ was optimum for polygalacturonase production. These optima are more pronounced if this production is measured at the same $a_{\mathrm{w}}$ of the growth medium and concerns the total biomass of each batch. Nevertheless, $a_{\mathrm{w}}$ seems to affect more the enzymatic reaction than the production of enzymes by a fungus. The osmoregulation of mycelial cells in order to preserve metabolic pathways, synthesis of proteins for example, might attenuate these differences.

Grajek and Gervais (1987) studied the influence of $a_{\mathrm{w}}$ on enzyme production by Trichoderma viride TS and obtained similar results to ours. The maximum production of $T$. viride polygalacturonase and xylanase occurred at $a_{\mathrm{w}} 1.00-0.99$. We conclude that the optimum $a_{\mathrm{w}}$ for the production and hydrolytic activity of these enzymes appears to be very close to the optimum $a_{w}$ for mycelial growth. Cellulase behaves differently, considering that the optimum $a_{\mathrm{w}}$ for enzyme production and activity is clearly below the optimum $a_{\mathrm{w}}$ for mycelial growth. This was suggested earlier by Hulme and Stranks (1971) with Myrothecium verrucaria.

Our results lead to several questions referring to the mechanism of the effect of $a_{\mathrm{w}}$ on enzyme synthesis and enzyme excretion. With regard to the latter, questions arise concerning the formation and the functioning of the fungal plasma membrane. It has been shown (Charlang ând Horowitz 1974) that $a_{\mathrm{w}}$ affects the fluidity of the membrane. Whereas these findings would offer a basis for a hypothesis on the role of $a_{\mathrm{w}}$ in mechanisms of protein export localized in the plasma membrane, there is still a complete lack of understanding with regard to its effect on enzyme synthesis.

\section{References}

Beuchat LR (1983) Influence of water activity on growth, metabolic activities and survival of yeasts and moulds. J Food Prot 46:135-141

Charlang G, Horowitz NH (1974) Membrane permeability and the loss of germination factor from Neurospora crassa at low water activities. J Bacteriol 117:261-264

Chou CC, Ho FM (1988) Effects of temperature and relative humidity on the growth of and enzyme production by Actinornucor tä̈wanesis during sufu pehtze preparation. Appl Environ Microbiol 54:688-692

Cooper RM, Wood RKS (1975) Regulation of synthesis of cellwall degrading enzymes by Verticillum albo-atrum and Fusarium oxysporum f.sp. lycopersici. Physiol Plant Pathol 5:135156

Gervais P, Sarrette M (1990) Influence of age of mycelium and water activity of the medium on aroma production by Trichoderma viride grown on solid substrate. J Ferment Bioeng $69: 46-50$

Gervais P, Belin JM, Grajek W, Sarrette M (1988) Influence of water activity on aroma production by Trichoderma viride TS growing on a solid substrate. J Ferment Technol 66:403-407

Grajek W, Gervais P (1987) Influence of water activity on the enzyme biosynthesis and enzyme activities produced by Trichoderma viride TS in solid state fermentation. Enzyme Microb Technol 9:658-662

Hahn-Hägerdal B, Nilsson M, Andersson E (1987) Synthesis of oligosaccharides and peptides using hydrolytic enzymes at decreased water activity. Ann NY Acad Sci : 193-196

Hulme MA, Stranks DW (1971) Regulation of cellulase production by Myrothecium verrucaria grown on non cellulosic substrates. J Gen Microbiol 69:145-155

Jurus AM, Sundberg WJ (1976) Penetration of Rhizopus oligosporus into soybeans in tempe. Appl Environ Microbiol 32:284-287

Kaji A, Yoshihara O (1969) $\alpha$-L-Arabinofuranosidase from Corticum rolfsiu. Appl Microbiol 910-913

Kikuchi T, Ishii S, Fuku Shima D (1971) Chemical and physical properties of soybean cell wall polysaccharides and their changes during cooking. Agric Biol Chem 34:228-234

Laretta-Garde V, Xu ZF, Biton J, Thomas D (1987) Stability of enzymes in low water activity media. In: Laane $\mathrm{C}$, Tramper $\mathrm{J}$, Lilly MD (eds) Biocatalysis in organic media. Elsevier Science Publishers, Amsterdam, pp 247-252

Liu YK, Luh BS (1978) Purification and characterization of endopolygalacturonase from Rhizopus arrhizus. J Food Sci $43: 721-726$

Manachini PL, Fortina MG, Parini C (1987) Purification and properties of an endo-polygalacturonase produced by Rhizopus stolonifer. Biotechnol Lett $9: 219-224$

Mattiasson B, Hähn-Hägerdal B (1982) Microenvironmental effects on metabolic behaviour of immobilized cells. Eur J Appl Microbiol Biotechnol 16:52-55

Norrish RS (1966) An equation for the activity coefficient and equilibrium relative humidities of water in confectionery syrups. J Food Technol $1: 25-39$

Nout MJR (1989) Effect of Rhizopus and Neurospora spp. on growth of Aspergillus flavus and $A$. parasiticus and accumulation of aflatoxin B1 in groundnut. Mycol Res 93:518-523

Nout MJR, Rombouts FM (1990) Recent developments in tempe research. J Appl Bacteriol 69:609-633 
Okolie PN (1988) Changes in activities of cell wall degrading enzymes during fermentation of cassava with Citrobacter freundi. J Sci Food Agric 44:51-61

Sachde AG, A-Bakir AY, Sarhan HR (1987) Effect of cultural conditions on the production of polygalacturonase from $R h i$ zopus arrhizus. Iraqi J Agric Sci "Zanco" 5:61-72

Shurtleff W, Aoyagi A (1979) The book of tempeh. Harper and Row, New York

Spiro RG (1966) Analysis of sugars found in glycoproteins. Methods Enzymol 8:3-26

Sudarmadji S (1977) Certain chemical and nutritional aspects of soybean tempeh. Doctoral Thesis, Michigan State University
Van de Riet WB, Wight AW, Cillier JJL, Datel JM (1987) Food chemical analysis of tempe prepared from South African grown soybeans. Food Chem 25:197-206

Voragen AGJ, Schols HA, Searle-van Leeuwen MF, Beldman G, Rombouts FM (1986) Analysis of oligomeric and monomeric saccharides from enzymatically degraded polysaccharides by high-performance liquid chromatography. J Chromatogr 370:113-120

Wang HL, Vespa JB, Hesseltine CW (1974) Acid protease production by fungi used in soybean food fermentation. Appl Microbiol 27:906-911

Whitaker JR (1978) Biochemical changes occurring during the fermentation of high protein foods. Food Technol 32:175-180 